\title{
THE EUROPEAN PUBLIC PROSECUTOR'S OFFICE - AN INSTITUTION WITH A FUNDAMENTAL ROLE IN DEFINING THE EUROPEAN SECURITY SPACE
}

\author{
E.-A. IANCU, C. JIGĂU
}

\section{Elena-Ana IANCU}

Professor Habil. PhD., Alexandru Ioan Cuza Police Academy, Doctoral School of Law, Bucharest, Romania / Faculty of Juridical and Administrative Sciences, Agora University of Oradea, Romania

*Correspondence: Elena-Ana Iancu, Agora University of Oradea, 8 Piaţa Tineretului St., Oradea, Romania

E-mail: anaelena2009@yahoo.com

\section{Cătălin JIGĂU}

PhD Student, "Alexandru Ioan Cuza" Police Academy, Doctoral School of Law, Bucharest, Romania / Ministerul de Justiție

E-mail: jigau_catalin@yahoo.com

\section{ABSTRACT:}

The security of the European space involves both an external and an internal component. The European authorities play an essential role in ensuring the internal security of the Community through both the security policy and the efficiency of the Community institutions. The European Public Prosecutor's Office represents a newly established institution, which through its form of organization as well as its attributions aims to ensure the internal security of the Community in the aspect of combating offenses against the financial interests of the European Union. By cooperating with the other European institutions and state authorities, the European Public Prosecutor's Office will play a decisive role in the fight against corruption.

KEYWORDS: security, EU financial interests, European Prosecutor's Office, cooperation, European institution.

\section{INTRODUCTION. CONSIDERATIONS REGARDING THE SECURITY OF THE EUROPEAN COMMUNITY AREA}

Democratic state in the XXI century has as one of its key pillars ensuring the security of its citizens, by reference to all the coordinates of the modern world. Thus, security is aimed at the possibility of exercising and respecting fundamental human rights, such as the right to life, liberty and others. However, the evolution of the concept of "security" has gained new strengths in the contemporary world, often referring not only to respecting certain rights but to the reality considered as a system that includes economic, social, cyber, traffic safety and other aspects. ${ }^{1}$

\footnotetext{
${ }^{1}$ https://www.caleaeuropeana.ro/editorial-sebastian-sarbu-despre-cultura-de-securitate/ - acces time: 14.11.2019, 20.30;
} 
In this context threats such as terrorism, cross-border crime or organized crime need to be combated by states through specially created institutions for this purpose, as well as by citizens, individually, through their direct participation in the recognition of these phenomena, their prevention and control. ${ }^{2}$

In view of the concrete contribution made by the citizens of the democratic state in maintaining security, it is necessary to bring to their knowledge all the information regarding the security values and needs - which may represent political, economic, military and other aspects. This creates the chance for development and at the same time promotes individual behaviors that work effectively against external or internal hazards. ${ }^{3}$ The sum of these actions and behaviors can be defined as the "culture of security", which needs to be constantly popularized in order to fulfill its social role.

From the point of view of the fulfillment by the states of the obligation to ensure the security of its citizens, it is necessary to specify the fact that at present the threats regarding it can be both external and internal, or in the special case of the European Union - of order Community.

With regard to internal threats, it should be specified that they can be generated from several sources, such as inefficiency of authorities and institutions, widespread corruption, political clientelism.

At present Romania as part of the European Union has an important role in ensuring community safety, especially since there is extra space in the immediate vicinity.

At the level of the European Union in 2010, the Internal Security Strategy of the European Union was adopted by the Council of Justice and Home Affairs, which was approved by the European Council in the same year.

The target of the aforementioned strategy is the protection of rights and freedoms, improving cooperation between Member States, reactive approach to security causes, establishing policies to prevent the state of insecurity, involving the whole society in combating the elements that generate the state of insecurity - such as politics, economic or the social, informing EU citizens of the measures taken by the authorities regarding the prevention or elimination of the states of insecurity, as well as the approach of the internal security status in interdependence with the external one. ${ }^{4}$

In order to ensure the security of the European Community space it is necessary to have a very good collaboration between the customs authorities as well as the other judicial authorities, as well as with the various public services existing in a state, such as the health, civil and civil protection sectors.

The Treaty of Lisbon was established Standing Committee on Operational Cooperation on Internal Security (COSI), this one will have a role in coordination and cooperation between law enforcement authorities and managing borders and issues related to operational cooperation in reference to judicial cooperation in criminal matters. ${ }^{5}$

\footnotetext{
${ }^{2}$ https://www.caleaeuropeana.ro/editorial-sebastian-sarbu-despre-cultura-de-securitate/- acces time 14.11.2019, 20.45;

${ }^{3}$ https://intelligence.sri.ro/cultura-de-securitate-surse-si-resurse/- acces time 14.11.2019;

4 www.consilium.europa.eu/infopublic - Internal Security Strategy of the European Union (Strategia de Securitate Internă a Uniunii Europene) - page 9, acces time 15.11.2019, 21.00;

5 www.consilium.europa.eu/infopublic- Internal Security Strategy of the European Union (Strategia de Securitate Internă a Uniunii Europene) - page 26, acces time 17.11.2019, 21.00;
} 
THE EUROPEAN PUBLIC PROSECUTOR'S OFFICE - AN INSTITUTION WITH A

FUNDAMENTAL ROLE IN DEFINING THE EUROPEAN SECURITY SPACE

At the same time, COSI has the task of ensuring good cooperation between EU agencies and bodies that have as their purpose the activity of internal security of the Union, such as Europol, Frontex, Eurojust, Cepol and Sitcen. ${ }^{6}$

EU security is also interdependent with respect for the rule of law within the Union. In this respect, the Member States have a very important role, the judicial system of each country being essential to be functional and efficient. Moreover, institutions that aim to ensure balance in society and maintain control of the rule of law have a major role in removing the attacks that may exist against the rule of law. ${ }^{7}$

However, the European institutions have an important responsibility in terms of the support they provide to national authorities in respect of the rule of law.

The internal security within the Union is required to be sustained also through European institutions that have direct attributions regarding the violation of the legal order, of the European values enshrined in the legislation. Failure to sanction conduct that violates such rules would represent a true departure from the order established in the rule of law.

In order to achieve an effective involvement of the Union in this regard, several institutions have been set up that play an important role in judicial cooperation, of which we mention OLAF - European Anti-Fraud Office, EUROPOL - European Police Office, EUROJUST and last but not least. EPPO - European Public Prosecutor's Office.

\section{BRIEF HISTORY OF THE ESTABLISHMENT OF THE EUROPEAN PUBLIC PROSECUTOR'S OFFICE}

Given the fact that OLAF, Eurojust and Europol are not competent in terms of carrying out criminal investigation for committing the crimes affecting the financial interests of the EU, the European Public Prosecutor intends to be an independent institution, which has just this task.

The need for the creation of the European Public Prosecutor's Office resulted from the difficulties encountered in the efforts made to protect the common European budget, amplified difficulties and by the different legislation of the EU Member States.

We consider that the establishment of the European Public Prosecutor is brought significant change in relation to how to protect EU funds, the efforts of nation states in this regard will be combined with European efforts.

The idea of setting up an independent body with direct attributions for conducting criminal investigations in the EU came up practically with the project of establishing a European judicial area in 1995.

In 1996, European Parliament President then in office, Klaus Hansch promoted this idea. ${ }^{8}$ In 1997 was launched the work "Corpus Juris" which brought together a series of rules

\footnotetext{
${ }^{6}$ Idem

${ }^{7}$ https://ec.europa.eu/transparency/regdoc/?fuseaction=list\&coteId=1\&year=2019\&number=343\&version=ALL $\underline{\text { \&language }=\text { ro }}-$ Communication from the Commission to the European Parliament, the European Council, the Council, the European Economic and Social Committee and the Committee of the Regions - Strengthening the rule of law within the Union - Action plan (Comunicare a Comisiei către Parlamentul European, Consiliul European, Consiliu, Comitetul Economic și Social European și Comitetul Regiunilor - Consolidarea statului de drept în cadrul Uniunii - Plan de acțiune) - page.10 - acces time 17.11.2019, 21.30;

${ }^{8}$ www.europa.eu - Press release from the European Commission, Protecting taxpayers' money against fraud (Comunicat de presă al Comisiei Europene, Protejarea banilor contribuabililor împotriva fraudelor): acces time 17.11.2019, 20.30.
} 
of criminal law and criminal procedure that were intended to be applied throughout the European area, while also dealing with the fraud of European funds. ${ }^{9}$

The idea of creating a European Public Prosecutor was reiterated in 2000, although in a different form, by proposing the idea of "European public prosecutor" by the European Commission on the occasion of the Intergovernmental Conference prior to the adoption of the Nice Treaty.

In 2001, the Green Paper on the protection within the criminal law of the financial interests of the Community and the establishment of a European Public Prosecutor was issued by the European Commission ${ }^{10}$, however, the idea of setting up the European Public Prosecutor's Office was abandoned.

Subsequently, by the Treaty of Lisbon, pursuant to Article 86 it was decided that "in order to combat offenses which harm the financial interests of the Union, the Council, acting by regulations in accordance with a special legislative procedure, may establish a European Public Prosecutor's Office, starting from Eurojust. The Council decides unanimously, after the approval of the European Parliament "11

The European Public Prosecutor's Office (EPPO) thus appears as a structure distinct from Eurojust, decentralized and guided by the principles of efficiency, independence and responsibility.

In the European Commission's vision, EPPO is based on the legal systems of the EU Member States and takes into account the national laws, its purpose being to act in a faster and more coherent way.

Although the Lisbon Treaty is not the one establishing the European Public Prosecutor's Office, it is an important step forward in this regard.

The real act establishing the EPPO is the EU Regulation, adopted on October 20, 2017 by twenty EU Member States, namely Germany, France, Italy, Belgium, Spain, Portugal, Greece, Austria, Luxembourg, Romania, Bulgaria, Croatia, Cyprus, Finland, Slovakia, Slovenia, Czech Republic, Estonia, Latvia and Lithuania, countries where the EPPO is to be competent to conduct criminal investigations.

The aforementioned Council Regulation, $2017 / 1939$ of 12 October 2017 on the implementation of a form of enhanced cooperation regarding the establishment of the European Public Prosecutor's Office was published in the Official Journal of the European Union, series L 283/1.

\section{EU REGULATION ESTABLISHING THE EPPO - PROVISIONS AND ISSUES REGARDING ITS IMPLEMENTATION}

Since the establishment of the EPPO, it is foreseen that EU Member States that have not participated in this form of cooperation can subsequently join it.

The EPPO headquarters is located in Luxembourg, with EPPO having legal personality and will be effective by the end of 2020 .

The regulation stipulates within the scope of art.4 as EPPO's attributions that "it has the power to investigate, prosecute and prosecute offenders who infringe the financial

\footnotetext{
${ }^{9}$ M. Delmas-Martz, J.A.E. Vervaele, La mise en oeuvreu du Corpus Juris dans les Etats Membres, Intersentia, Antwerpen-Groningen-Oxford, 2000;

${ }^{10}$ O. Ținca, General Community Law, ed. III, Lex Light Publishing House, Bucharest, 2005 (Drept comunitar general, ediţia a III-a, Ed. Lumina Lex, București, 2005), p. 301.

${ }^{11}$ E. Dragomir, D. Niță, Treaty of Lisbon - entered into force on December 1, 2009, Nomina Lex Ed., Bucharest, 2010 (Tratatul de la Lisabona - intrat în vigoare la 1 decembrie 2009, Ed. Nomina Lex, București, 2010), p. 176.
} 
THE EUROPEAN PUBLIC PROSECUTOR'S OFFICE - AN INSTITUTION WITH A

FUNDAMENTAL ROLE IN DEFINING THE EUROPEAN SECURITY SPACE

interests of the Union [provided in Directive (EU) 2017/1371 and established in this Regulation] and their accomplices. In this regard, the EPPO conducts investigations, carries out criminal investigations and exercises the public action in the competent courts of the Member States, until the end of the case. "

Article 5 of the same regulation establishes the general principles of the EPPO activity. Thus, it is guided by the principles of the rule of law, which will respect the rights provided in the charter. Within the same article it is provided the pre-eminence of the provisions of the regulation with respect to the national law of each state, the latter being applicable only if there are no corresponding provisions in the regulation. At the same time, it is foreseen that the applicable national law is that of the European prosecutor delegated to investigate the case.

Article 6 of the Regulation expressly mentions the independence of the EPPO Chief Prosecutor, Deputy Prosecutors, European and Delegate Prosecutors, as well as other categories of EPPO personnel, as they cannot receive instructions from any other person. outside EPPO.

From the perspective of Romanian national law, the provisions of art.6 of the aforementioned Regulations contradict the depositions of art.132 paragraph 1 of the Constitution of Romania which provide in the case of prosecutors the principle of hierarchical subordination, as well as with the provisions of art.64 paragraph 1 of the Organizing Law Judiciary 304/2004 which enshrines the same principle.

In the Romanian law only the provisions of Law 303/2004 establish the prosecutor's independence, but under the conditions of the law.

However, although according to the provisions of Article 6 of the Regulation, the independence of the institution of the European Public Prosecutor's Office is established, the delegated European prosecutors cannot be considered independent, as they are related to the instructions and decisions of the European prosecutors who supervise them or the permanent chamber.

Art.8 of the Regulation presents the structure of the EPPO, which carries out its activity independently and is organized on two levels, one central or European and one decentralized or state. ${ }^{12}$

Paragraph 3 of Article 8 of the Regulation states that as regards the central level, it consists of the college, the permanent chambers, the European chief prosecutor, the deputy chief European prosecutors, the European prosecutors - those representing the participating states and the administrative director.

The decentralized level is represented by the delegated European prosecutors, according to the provisions of the same article.

As regards the EPPO College, Article 9 of the Regulation provides that its composition includes the European Chief Prosecutor, as well as one European Prosecutor from each Member State.

The tasks of the EPPO College consist of taking decisions on strategic issues and general issues, in order to ensure an effective, coherent and consistent policy of EPPO regarding the stage of criminal prosecution in the Member States, as well as on other matters strictly regulated by the Regulation. . The college cannot have any involvement in direct decisions on individual cases.

\footnotetext{
${ }^{12}$ Regulation EU (Regulamentul UE) - Annex no. 7 (Anexa nr. 7);
} 
The College also has the task of establishing permanent chambers, as well as the adoption of the internal operating regulations. Decisions within the college are taken by simple majority, in accordance with Article 9 paragraph 5 of the Regulation.

The permanent chambers are chaired by the European Chief Prosecutor, one of the Deputy Prosecutors or a European Prosecutor appointed for this purpose.

The number of permanent rooms is adapted to the specific needs of the EPPO, and the volume of activity is distributed evenly through a random system.

One of the most important tasks of the permanent chambers is to monitor and direct the investigations and activities of criminal prosecution carried out by the delegated European prosecutors.

Article 11 of the Regulation presents the duties of the European Chief Prosecutor, as well as of his two deputies. Thus, according to the aforementioned article "the European Chief Prosecutor organizes the activity of the EPPO, conducts its activities and makes decisions in accordance with this Regulation and the internal rules of procedure of the EPPO". According to paragraph 2 of the same article, the deputies of the chief prosecutor assist him or substitute him in case of impossibility to exercise the powers.

It is worth mentioning that the European Chief Prosecutor has the power to represent the EPPO, both in front of the EU Member States, of the European institutions and of any third party, these powers being delegated to the deputies.

Regarding the attributions and role of European prosecutors, the provisions of art.12 of the Regulation provide that as their main task the supervision of investigations and prosecutions carried out by the delegated European prosecutors, who can also receive instructions. Also, European prosecutors are preparing draft decisions on the cases they supervise that they submit to the permanent chamber.

According to paragraph 5 of the aforementioned article, European prosecutors act as "liaison and information channel between the permanent chambers and the European prosecutors delegated in their respective Member States of origin."

The powers of the delegated European prosecutors are specified in Article 13 of the Regulation. According to the provisions of the aforementioned article, they act in the Member States on behalf of the EPPO, having the same powers as those of the national prosecutors, respecting the limits of the regulation.

In view of the clear provisions of the Regulation which set for example the task of the permanent chamber to issue the decision to refer to the court, the question which naturally arises is if this double status of the delegated European prosecutors (PEDs) is likely to make the activity more efficient for them, or is just a formality lacking in content ${ }^{13}$.

This discussion needs to be further deepened as paragraph 2 of Article 13 provides for the responsibility of European prosecutors for investigations or prosecutions with which they have been invested in one way or another, although the fact remains that they must follow the instructions of the standing room or the instructions of the European prosecutor in charge.

Moreover, in the following paragraph it is shown that the PED is responsible for the trial, can plead, participate in obtaining evidence and exercise the remedies in accordance with national law.

\footnotetext{
${ }^{13}$ M. Coninsx, The European Commission's Legislative Proposal: An Overview of Its Main Characteristics, pct. 3.5.1, An Office at EU Level Directing Double Hatted European Delegated Prosecutors, p. 32-33, în „,The European Public Prosecutor's Office, An Extended Arm or a Two-Headed Dragon?", de L.H. Erkelens, A.W.H. Meij, M. Pawlik, Editors, Asser Press, The Hague and Spriger - Verlag, Berlin, Heidelberg, 2015.
} 
THE EUROPEAN PUBLIC PROSECUTOR'S OFFICE - AN INSTITUTION WITH A

FUNDAMENTAL ROLE IN DEFINING THE EUROPEAN SECURITY SPACE

To the extent that practically any act of the EDP is conditioned by authorizations given by the permanent chamber or the European prosecutor, often the instructions being given in written form, it turns out that it is in fact deprived of any decision-making power. Thus, from the opening of the case to the prosecution or the exercise of the remedies, the Regulation provides for detailed procedures, which provide as we have shown the authorization of the acts performed by the PED.

In this context, we naturally consider the question to what extent the PED could be held responsible for all these acts, on which it cannot decide. Eventually we appreciate that the only theme of his responsibility could be the fidelity to the reality of the information offered to the European prosecutor or the permanent chamber. Reported to the multitude of decision-making powers of the permanent chamber (elaboration of instructions to the EDP to initiate an investigation, the allocation or reallocation of a case, the approval of the decision of a European Prosecutor to carry out the criminal prosecution himself, as well as to decide on the trial, the closing or reopening of a case, to apply a simplified procedure and others ${ }^{14}$ ) the powers of the EDP in terms of the possibility of making decisions are practically non-existent, his dual quality as a national prosecutor having the capacity to give instructions to the authorities of the Member State being practically devoid of any efficiency.

The organization of the EPPO thus appears to be a way in which decisions are most often made at the collegiate level, by majority vote, even the actions of European prosecutors being meant to be authorized under certain conditions. We appreciate that this way of structuring and functioning can ensure a balance in decision making, which are thus carefully analyzed. Moreover, we appreciate that the entire structure of the EPPO has the role of representing within the European community a factor of unity and balance, which has as its final purpose the assurance of the internal security of the community space, in the aspect of combating offenses that harm the financial interests of the European Union or participation in a criminal organization for this purpose.

Regarding the material competence of the EPPO, art.22 of the Regulation states that it is competent to solve the offenses that harm the financial interests of the Union, which are provided in the Directive (EU) 2017/1371, regardless of the form in which they are transposed into national law. of EU member states. Article 22, paragraph 1, thesis 2 -a of the Regulation mentions in respect of the offenses referred to in Article 3 (2) (d) of Directive (EU) 2017/1371, as transposed in the national legislation, that EPPO " it shall be competent only where the intentional acts or inactions defined in that provision relate to the territory of two or more Member States and involve a total damage of at least EUR 10 million. "

In the report of the Framework Decision 2008/841 / JHA EPPO is competent to solve the crimes related to the participation in a criminal organization that are committed in order to harm the financial interests of the European Union, as well as any criminal behavior related to it, so after is mentioned in paragraph 3 of Article 22 of the Regulation.

Article 23 of the Regulation establishes its territorial competence, in the sense that the EPPO is competent to solve cases that have been committed in whole or in part within the European Union, by a national of a Member State that has competence in this regard or outside the EU territories. , if the provisions of the Staff Regulations or the Regime applicable

\footnotetext{
${ }^{14}$ Council Document no. 10830/16 of Julay 11, 2016 (art. 9) (Documentul Consiliului nr. 10830/16 din 11 iulie 2016 (art. 9), pages. 11 - 15
} 
at the time of the offense are incurred against the respective person and the Member State is competent to that effect.

By establishing the object of the EPPO's material competence in offenses that harm the EU's financial interests, it was considered better management of this type of crime, which raises EU-wide because of differences in national legislation and cumbersome procedures for cooperation.

By establishing a unique mechanism for investigating this type of crime, we believe that the EU's financial interests will be better protected, thus ensuring better financial security for EU citizens, whose financial funds are channeled at least to the Community budget.

The possibility of using community funds more effectively, in the absence of fraud, will implicitly lead to a better standard of living, in which the rights of European citizens will be more respected.

Moreover, in order to effectively achieve the purposes for which it was set up, the EPPO by Regulation benefits from a special criminal investigation and prosecution procedure, which is complemented with that of the national states at the trial stage.

Thus, according to article 37 paragraph 1 of the Regulation "The admission of the evidence presented by the EPPO prosecutors or the defendant before a court is not rejected for the simple reason that the evidence was obtained in another Member State or in accordance with the law of another State member. "

The principle of the default value of the evidence is found in paragraph 2 of the same article, which stipulates the right of the court to "... freely evaluate the evidence presented by the defendant or the prosecutors within the EPPO", which is not affected by the provisions of the regulation .

Although the aforementioned provision is appreciated that it considered the efficiency of the EPPO activity, it remains susceptible to critical analysis.

Thus, it can be observed that paragraph 2 of the mentioned article refers only to the probative value of the means of proof and does not concern the examination of its legality. Problems may arise if a sample is presented by the EPPO before the court of a state other than the one where the sample was administered. To the extent that it would be appreciated that the method of administering the evidence is one that is vitiated by the law of the state in which the evidence is presented, the natural solution would be to reject the sample, being struck by nullity. However, the provisions of art.37 of the Regulation do not seem to accept such a solution, from its prism the samples to be analyzed only in terms of solidity and not of legality.

And regarding the EPPO referral, we consider that there may be some problems in practice regarding the effective application of the Regulation.

Thus, according to Article 24 of the Regulation "The institutions, bodies, offices and agencies of the Union and the authorities of the competent Member States under the applicable national law immediately denounce to EPPO any criminal behavior for which it may exercise its competence." There may be problems in relation to the security and legislative system of each Member State insofar as the intelligence services communicate aspects related to the commission of offenses to authorities other than national ones.

To the extent that there is currently no information community at European level and no European regulations implemented at Member State level, the information services may not directly report to EPPO the information they hold, but only communicate it to national authorities. 
THE EUROPEAN PUBLIC PROSECUTOR'S OFFICE - AN INSTITUTION WITH A

FUNDAMENTAL ROLE IN DEFINING THE EUROPEAN SECURITY SPACE

Of course, the Regulation adopted at present can be considered as vulnerable in terms of its applicability in relation to certain aspects it deals with. Its purpose, however, remains to make EPPO a functional prosecutor's office, which will contribute to the internal security of the Union, through an effective fight against fraud, and thus to the creation of a European security space.

Moreover, in this "fight" EPPO is not alone, the Regulation itself contain several provisions regarding its collaboration with other European or national institutions with a similar purpose.

Thus, according to art.99 of the EPPO Regulation establishes and "maintains cooperative relations with the institutions, bodies, offices and agencies of the Union".

Further, in the art.100 of the same Regulation it is shown that regarding the collaboration with Eurojust it must be based on mutual cooperation and the development of the links between the two institutions, EPPO having access to the information contained in the case management system belonging to Eurojust.

OLAF is another European institution, according to which, according to article 101 of the EPPO Regulation, it maintains a close relationship of cooperation and exchange of information. The provisions of paragraph 1 of the aforementioned article mention that it is important to collaborate with OLAF especially in terms of ensuring "the use of the means available for the protection of the financial interests of the Union". Similarly, EPPO has access to the information contained in the case management system belonging to OLAF.

It is worth mentioning that in the situation where the EPPO conducts a criminal investigation, OLAF can no longer carry out an administrative investigation regarding the same facts.

EPPO also maintains collaborative relations with EUROPOL, the provisions of art. 102 of the Regulation stipulating that an agreement is concluded between the two institutions. EPPO can obtain support from EUROPOL, both in terms of the requested information and analytical support.

EPPO maintains cooperative relations with the European Commission, third countries and international organizations, as well as with the Member States of the European Union that do not participate in the form of enhanced cooperation with regard to the establishment of EPPO, as is clear from the provisions of Articles 103, 104 and 105 of the Regulation.

We appreciate that by establishing cooperative relations between the EPPO and the main European institutions, as well as in relation to third parties, its role is strengthened, its activity optimized, as a final goal the state of internal security of the European Union being strengthened.

\section{CONCLUSIONS}

The fight against fraud in the European budget has proven to be quite difficult from its inception, especially given the national laws of the EU Member States which differentiate how to investigate the facts. In view of the annual losses suffered by the Union, it was necessary to identify a solution in this regard. The establishment of the European Public Prosecutor's Office is the answer found by the Union, taking criminal investigations into the offenses that affect the European budget being able to streamline the fight against fraud.

We appreciate that although perfectable, the way of functioning and organization of the European Public Prosecutor's Office, as established by the Regulation, is capable of 
effectively combating fraud against European funds. The cross-border character of the EPPO, doubled by the unitary way of conducting the criminal investigation, prefigures a unique model of judicial body, which may represent a perspective for other European institutions.

Effective protection of European funds will lead to a higher standard of living throughout the Union, stimulate the emergence of new jobs, support for medical and education systems in member countries and beyond. The actions of the European Public Prosecutor's Office will inhibit the maintenance or promotion of a state of corruption at the level of the Member States, thus protecting the interests of the European citizen and thus contributing to ensuring a state of internal security, both at national and at Community level.

We appreciate that, in the future, starting from the EPPO model contained in the Regulation, its competence could be extended to other types of crime, especially for those with a cross-border character.

Security at EU level will be strengthened by the creation of a common European judicial space, with a first EPPO institution representing an important step in its development. ${ }^{15}$

At the same time, we appreciate that the impact that the newly established EPPO institution will have on the Romanian judicial system will be an important one, the Regulation being directly applicable.

The fact that currently the European institutions can legislate has contributed to the improvement of judicial cooperation in criminal matters.

Thus, by setting up the EPPO the European Union can intervene in the definition of common procedures, so that certain offenses that have a major impact on the living standards within the Union, such as offenses that harm the EU's financial interests, are easier to combat.

The establishment of the European Public Prosecutor's Office represents an effective guarantee that the rights of the citizens of the European Union will be respected and thus the European space will be better secured.

\section{BIBILIOGRAPHY:}

M.Delmas-Martz, J.A.E. Vervaele, La mise en oeuvreu du Corpus Juris dans les Etats Membres, Intersentia, Antwerpen-Groningen-Oxford, 2000;

E. Dragomir, D. Niță, Tratatul de la Lisabona - intrat în vigoare la 1 decembrie 2009 (Treaty of Lisbon - entered into force on December 1, 2009) Nomina Lex Ed., Bucharest, 2010;

M. Coninsx, The European Commission's Legislative Proposal: An Overview of Its Main Characteristics, pct. 3.5.1, An Office at EU Level Directing Double Hatted European Delegated Prosecutors, p. 32-33, în ,The European Public Prosecutor's Office, An Extended Arm or a Two-Headed Dragon?", de L.H. Erkelens, A.W.H. Meij, M. Pawlik, Editors, Asser Press, The Hague and Spriger - Verlag, Berlin, Heidelberg, 2015;

O. T,inca, Drept comunitar general (General Community Law), ed. a III-a, Ed. Lumina Lex, Bucharest, 2005;

\footnotetext{
${ }^{15}$ F.R. Radu, Some considerations on the proposal for a Council Regulation establishing the European Public Prosecutor's Office and the proposal for a Regulation of the European Parliament and of the Council on the European Union Agency for Cooperation in Criminal Justice (Eurojust), in the journal European Legal Affairs, no. 2/2013, ( Câteva consideraţii asupra propunerii de Regulament al Consiliului de instituire a Parchetului European şi propunerii de Regulament al Parlamentului European și al Consiliului privind Agenţia Uniunii Europene pentru Cooperare în Materie de Justiţie Penală (Eurojust), în revista Afaceri juridice europene, nr. 2/2013) p. 15.
} 
THE EUROPEAN PUBLIC PROSECUTOR'S OFFICE - AN INSTITUTION WITH A

FUNDAMENTAL ROLE IN DEFINING THE EUROPEAN SECURITY SPACE

F.R. Radu, Some considerations on the proposal for a Council Regulation establishing the European Public Prosecutor's Office and the proposal for a Regulation of the European Parliament and of the Council on the European Union Agency for Cooperation in Criminal Justice (Eurojust), in the journal European Legal Affairs, no. 2/2013,( Câteva consideraţii asupra propunerii de Regulament al Consiliului de instituire a Parchetului European și propunerii de Regulament al Parlamentului European și al Consiliului privind Agenția Uniunii Europene pentru Cooperare în Materie de Justiție Penală (Eurojust), în revista Afaceri juridice europene, $n r .2 / 2013)$

Regulation EU (Regulamentul UE) - Annex no. 7 (Anexa nr. 7);

https://www.caleaeuropeana.ro/editorial-sebastian-sarbu-despre-cultura-de-securitate;

https://intelligence.sri.ro/cultura-de-securitate-surse-si-resurse/;

www.consilium.europa.eu/infopublic;

https://ec.europa.eu/transparency/regdoc/?fuseaction=list\&coteId=1\&year=2019\&num ber $=343 \&$ version $=$ ALL\&language $=$ ro ;

www.europa.eu - Press release from the European Commission, Protecting taxpayers' money against fraud (Comunicat de presă al Comisiei Europene, Protejarea banilor contribuabililor împotriva fraudelor);

Council Document no. 10830/16 of Julay 11, 2016 (art. 9) (Documentul Consiliului nr. 10830/16 din 11 iulie 2016 (art. 9). 